\title{
Protein quality of feeding-stuffs
}

\section{3.* Comparative assessment of the protein quality of three fish meals given to growing pigs}

\author{
BY R. S. BARBER, R. BRAUDE, $†$ A. G. CHAMBERLAIN, $\ddagger$ \\ ZENA D. HOSKING AND K. G. MITCHELL, \\ National Institute for Research in Dairying, Shinfield, Reading
}

(Received I3 April 1964-Accepted 6 fuly 1964)

It has been recognized for some time that the use of crude protein content as an indicator of the value of a protein supplement has limitations. The Protein Quality Group of the Agricultural Research Council is engaged in collaborative studies of various laboratory methods for evaluating protein supplements (Boyne, Carpenter $\&$ Woodham, 196r ; Bunyan \& Woodham, 1964). Some of these methods show considerable promise and their validity, when applied to protein supplements for pigs, has been investigated in the work now described in collaboration with the ARC Group.

Three fish meals, all of approximately the same crude protein content $(64-65 \%)$, were used. Fish meal FM 24 was recognized by the trade as of good quality, and laboratory tests supported this appraisal. Fish meal FM 25 was classified by the trade as low-grade, 'fertilizer meal', but was found in laboratory tests to be as good as FM 24. Fish meal FM 26 was classified as of very poor quality by both the trade and laboratory tests. FM 24 was made in Britain; FM 25 and 26 were from Peru.

The three fish meals were subjected to exhaustive chemical and microbiological laboratory tests and biological evaluation with chicks and rats. The details and results of these tests have been reported on behalf of the Protein Quality Group by Bunyan \& Woodham (1964).

\section{EXPERIMENTAL}

\section{Treatments and diets}

Three experiments were made and the treatments are set out in Table $r$. In the first, the three fish meals were included in the rations at a level frequently recommended for growing pigs at the present time, namely $7 \%$ of the ration for pigs up to I $20 \mathrm{lb}$ live weight and $3 \%$ thereafter to slaughter at bacon weight.

In the second experiment, the three fish meals were included in rations at a level arbitrarily set low: it was $3 \%$ of the ration up to $120 \mathrm{lb}$ live weight and $1 \frac{1}{2} \%$ thereafter to slaughter at bacon weight. Two other diets were included, one with FM 24 at $7 \%$ reduced to $3 \%$ as in Expt I (a positive control treatment) and the other with no fish meal (a negative control treatment).

In the third experiment, nitrogen digestibility and retention were measured in pigs

- Paper no. 2: Brit. F. Nutr. (1964), 18, 537.

+ Acting on behalf of the Agricultural Research Council Protein Quality Group.

$\ddagger$ Present address: University College of North Wales, Bangor. 
given rations cach of which contained one of the three fish meals at the marginal level of supplementation ( $3 \%$ ), up to slaughter at a weight of approximately $130 \mathrm{lb}$.

Table I shows the percentage of fish meal in the experimental rations and indicates the meal mixtures used. The composition of the meal mixtures is given in Table 2 and the chemical composition of the separate ingredients, together with the calculated chemical composition of each mixture, in Table 3.

Table $\mathrm{I}$. Treatments and rations given to pigs in the three experiments

\begin{tabular}{|c|c|c|c|c|}
\hline \multirow[b]{2}{*}{$\begin{array}{l}\text { Expt } \\
\text { no. }\end{array}$} & \multirow[b]{2}{*}{ Treatment } & \multirow[b]{2}{*}{$\begin{array}{l}\text { Fish meal } \\
\text { code no. }\end{array}$} & \multicolumn{2}{|c|}{$\begin{array}{l}\% \text { of fish meal in ration } \\
\text { (code letter in parentheses) }\end{array}$} \\
\hline & & & $\begin{array}{l}\text { Up to } 120 \mathrm{lb} \\
\text { live weight }\end{array}$ & $\begin{array}{l}\text { From I } 20 \mathrm{lb} \\
\text { to slaughter }\end{array}$ \\
\hline I & $\begin{array}{l}1 \\
2 \\
3\end{array}$ & $\begin{array}{l}F_{24} \\
F_{23} \\
F_{21}\end{array}$ & $\begin{array}{l}7(\mathrm{~A}) \\
7(\mathrm{~B}) \\
7(\mathrm{C})\end{array}$ & $\begin{array}{l}3\left(\mathrm{~A}_{\mathrm{I}}\right) \\
3\left(\mathrm{~B}_{\mathrm{I}}\right) \\
3\left(\mathrm{C}_{\mathrm{I}}\right)\end{array}$ \\
\hline 2 & $\begin{array}{l}\mathrm{I} \\
\mathrm{Ia} \\
2 \mathrm{a} \\
3^{\mathrm{a}} \\
4\end{array}$ & $\begin{array}{l}F M_{24} \\
F M_{24} \\
F M_{25} \\
F M_{26} \\
\text { None }\end{array}$ & $\begin{array}{l}7 \text { (A) } \\
3 \text { (D) } \\
3 \text { (E) } \\
3 \text { (F) } \\
0(\mathrm{G})\end{array}$ & 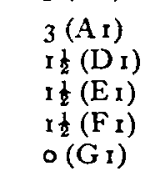 \\
\hline 3 & $\begin{array}{l}1 \mathrm{a} \\
2 \mathrm{a} \\
3 \mathrm{a}\end{array}$ & $\begin{array}{l}F M_{24} \\
\text { FM } 25 \\
\text { FM } 26\end{array}$ & $\begin{array}{l}3(\mathrm{D}) \\
3(\mathrm{E}) \\
3(\mathrm{~F})\end{array}$ & I \\
\hline
\end{tabular}

\section{Pigs and procedure}

Expts I and 2. Weaners, 9-1o weeks old from the Shinfield enzootic pneumonia-free Large White herd, were used. In these experiments of randomized block design, the twelve blocks each consisted of three litter-mate pigs of similar initial weight in the first experiment and of five litter-mates in the second. A. similar number of male and female pigs received each diet.

In both experiments, pigs receiving the same treatment were housed together in pens holding four pigs each. Twice daily the pigs were let into individual feeding compartments for about ${ }_{2} h$ on each occasion. The pigs were weighed once weekly and were rationed according to the Shinfield scale (Braude \& Mitchell, 1951), based on live weight, for restricted feeding of growing pigs. The meal ration was mixed with water immediately before feeding at the rate of $3 \mathrm{lb}$ water/lb meal. As each pig reached a live weight of $120 \mathrm{lb}$ at the weekly weighing, its ration was changed to the appropriate ration containing less fish meal, and when it weighed about $205 \mathrm{lb}$ it was sent to slaughter. After slaughter, carcass measurements including length, back-fat thickness at shoulder and loin, and measurements on the cut (at the last rib) side, were taken as prescribed by Buck, Harrington \& Johnson (1962).

Expt 3. Six groups of three castrated male litter-mate pigs, about 8-9 weeks old and of similar weight, were selected. The three experimental treatments were allocated at random to the three pigs in each group. Each pig was housed individually in a centrally heated piggery (thermostat set at $60^{\circ} \mathrm{F}$ ) and, during the ist week, the pigs were placed 


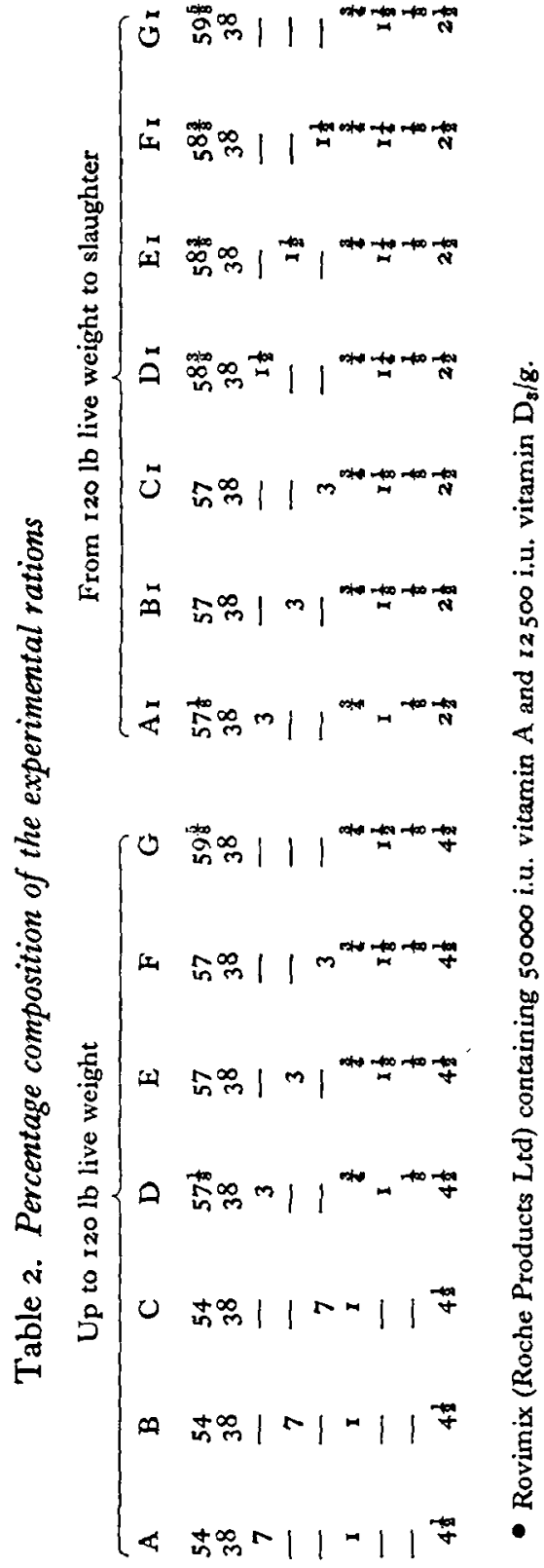

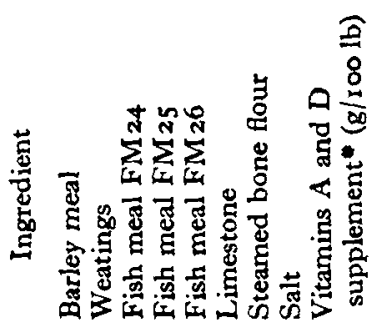

䞤产

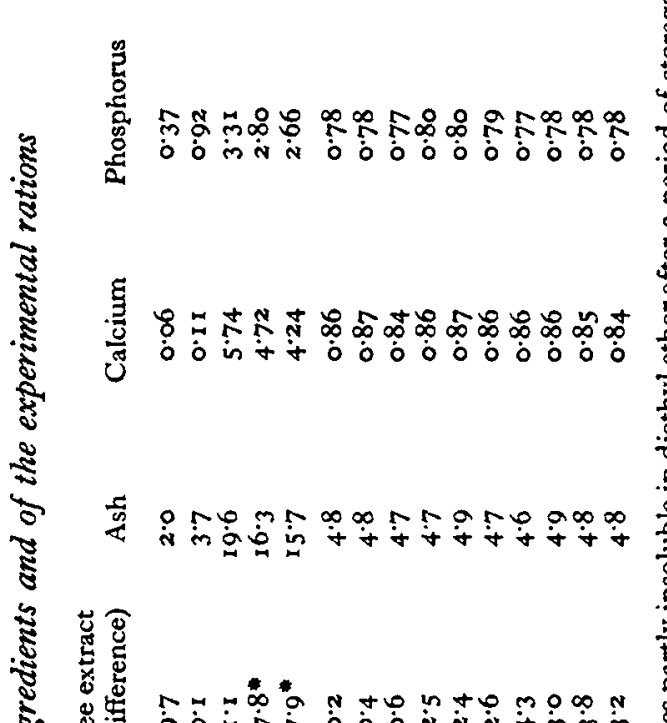

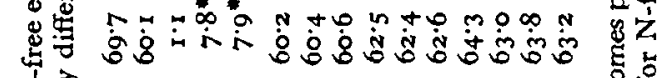
है 它急 总草

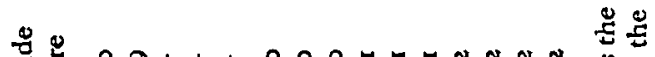

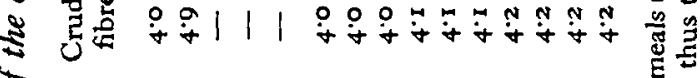

. 氙 要 . 至若 峞

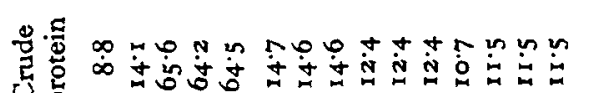
总 究 蓆 กิํㅠㅇ

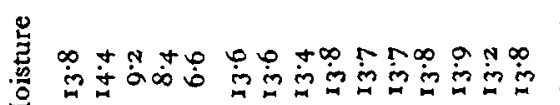
点 蛅

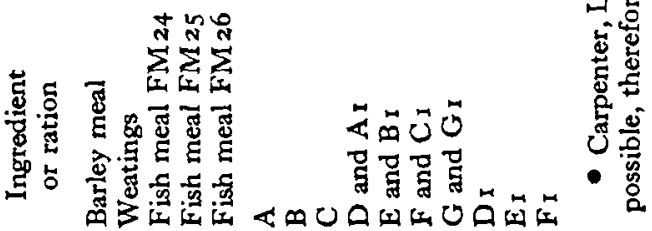
Nutr. 18,4 
for short periods each day in metabolism cages in the same building to accustom them to the experimental routine. The metabolism cages are described in detail by Allen, Barber, Braude \& Mitchell (1963).

During the experiment, two different groups of pigs were put into the cages on alternate weeks so as to obtain maximum use from the three cages available. Animals were placed in the cages on Monday mornings, collection periods beginning at noon on that day and continuing for 4 days until noon the following Friday. A light harness and faeces-collection apron permitted complete separation of urine and faeces. In all, four collections were made from each pig over a 7 -week jeriod.

Urine was collected in Polythene containers and glacial. acetic acid was used as the preservative. Twice daily the volume of urine was meast.red and a $10 \%$ sample was retained. The samples for each pig for each of the collection periods were subsequently combined and a portion was taken for $\mathrm{N}$ determination by the Kjeldahl method.

Faeces were collected twice daily and stored in screw-top glass jars in a refrigerator at $2-4^{\circ}$. At the end of each collection period the faeces of each pig were bulked and thoroughly mixed in a Hobart mixer, and a sample was taken and kept in a tightly sealed Polythene bottle for subsequent $\mathrm{N}$ determination by the Kjeldahl method.

The pigs were weighed at the beginning and end of each collection period and once during the alternate weeks when they were in the pens. They were fed in a similar manner to the pigs on treatments $\mathrm{r} a, 2 \mathrm{a}$ and $3 \mathrm{a}$ in Expt 2. . The test ended on completion of the fourth collection period, when the pigs were sent to slaughter. The measurements recorded during the trial permitted the calculation of total $\mathrm{N}$ consumed, total $\mathrm{N}$ in urine and in faeces, total $\mathrm{N}$ retained and apparent $\mathrm{N}$ digestibility.

\section{RESULTS}

Expt I. Mean values and appropriate standard errors for daily live-weight gain and efficiency of food conversion are given in Table 4 , which also contains the results of significance tests. The performance of pigs given fish meal FM 26 was inferior to that of pigs receiving the rations containing fish meals FMI $25(P<0.001)$ and FM 24 ( $P<0.05$ for daily gain and $P<0.001$ for food conversion), but there was no significant difference between rations containing FM 24 and 25 .

Mean values for carcass measurements are given in Table 5 , together with standard errors. Differences between treatments were statistically not significant $(P>0.05)$.

Expt 2. Two pigs died during the early stages of this, test for reasons unconnected with the experimental treatments: one was on treatment I ( $7 \%$ of fish meal FM 24) and the other, not a litter-mate, on treatment 4 (no fish-meal supplement). Missing values were calculated and appropriate adjustments made in the subsequent statistical treatment of the results. Table 6 gives the mean values for daily live-weight gain and efficiency of food conversion, with standard errors, and the results of significance tests. Three comparisons are most relevant to the problem studied:

(I) Comparison between treatments $\mathrm{I}, \mathrm{I}$ a and 4 in which rations with 7,3 or $0 \%$ fish meal FM 24 were compared indicated that the choice of $3 \%$ supplementation was reasonable for comparison of the three fish meals. With fish meal of good quality 
Table 4. Expt I. Mean daily live-weight gain and efficiency of food conversion of pigs given a fish-meal supplement (FM 24, 25 or 26) of $7 \%$ of the ration up to $120 \mathrm{lb}$ and of $3 \%$ thereafter (twelve pigs per treatment)

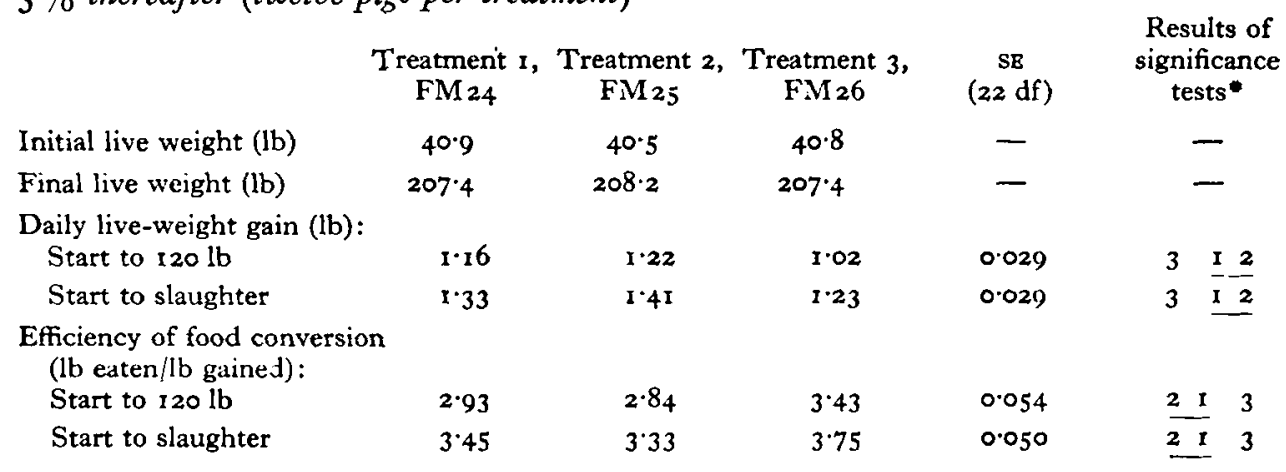

- The mean values differ significantly $(P=0.05)$ except when they share a common underlining (Duncan, 1955).

Table 5. Expt I. Mean carcass measurements* (mm) of pigs given a fish-meal supplement (FM 24, 25 or 26 ) of $7 \%$ of the ration up to $120 \mathrm{lb}$ and of $3 \%$ thereafter (twelve pigs per treatment)

$\begin{array}{lcccc} & \begin{array}{c}\text { Treatment I, } \\ \text { FM 24 }\end{array} & \begin{array}{c}\text { Treatment 2, Treatment 3, } \\ \text { FM 25 }\end{array} & \begin{array}{c}\text { SE } \\ \text { FM 26 }\end{array} & \text { (22 df) } \\ \begin{array}{lccc}\text { Length of side } \\ \text { Back-fat thickness: }\end{array} & 790 & 790 & 790 & 5 \cdot 7 \\ \text { Shoulder } & & & & \\ \text { Loin } & 52 & 54 & 54 & 1 \cdot 1 \\ \text { Eye muscle: } & 31 & 33 & 31 & 1 \cdot 1 \\ \text { Width } & & & & \\ \text { Depth } & 83 & 80 & 82 & 2 \cdot 2 \\ \text { Fat: C } & 42 & 45 & 43 & 1 \cdot 0 \\ \text { K } & 32 & 32 & 32 & 1 \cdot 4 \\ \text { J } & 52 & 54 & 52 & 1 \cdot 5 \\ & 7 & 7 & 7 & 0.5\end{array}$

None of the treatment differences was statistically significant at $P=0.05$.

- Taken according to Buck et al. (1962).

(FM 24), pigs receiving the marginal level of supplementation ( $3 \%$, treatment I a) performed much better than pigs receiving rations with no protein supplement (treatment 4$)$ and rather worse than pigs receiving the higher level ( $7 \%$, treatment $\mathrm{I})$.

(2) Comparison between treatments $\mathrm{ra}, 2 \mathrm{a}$ and $3^{\mathrm{a}}$ indicated that, whereas the performance of pigs receiving rations containing fish meal FM 24 or 25 did not differ significantly, it was markedly superior to that of the pigs given the rations with FM $26(P<0.001)$.

(3) Comparison between treatments 3 a and 4 showed that the performance of the pigs receiving the ration containing $3 \%$ of the inferior fish meal (FM 26) was not significantly better than of pigs receiving rations without any fish-meal supplement.

Table 7 gives mean values for carcass measurements of the pigs on the five treatments, with appropriate standard errors. Differences between treatments were not 


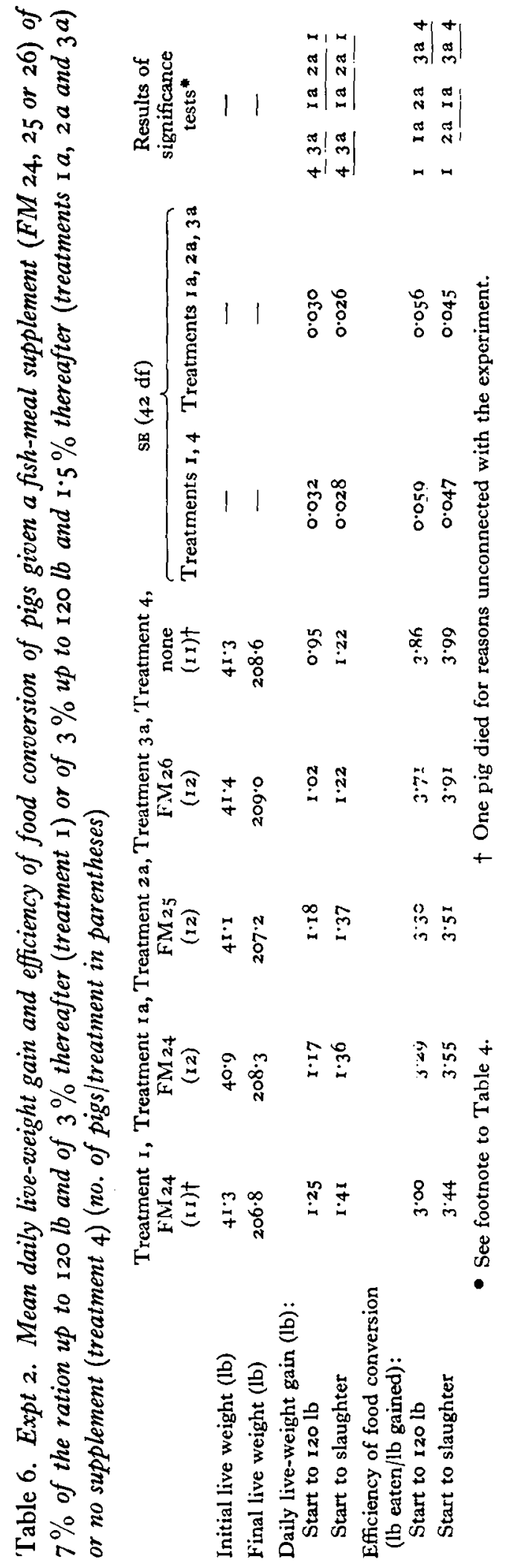


significant $(P>0.05)$ for any measurement other than the depth of eye muscle. Pigs on treatment 4 (no fish meal) had significantly less depth of eye muscle than pigs receiving any of the other four treatments $(P<0.05)$.

Table 7. Expt 2. Mean carcass measurements* ( $\mathrm{mm}$ ) of pigs given a fish-meal supplement (FM 24, 25 or 26) of $7 \%$ of the ration up to 120 lb and of $3 \%$ thereafter (treatment $\mathrm{I}$ ) or of $3 \%$ up to $\mathrm{I} 20 \mathrm{lb}$ and $\mathrm{I} 5 \%$ thereafter (treatments $\mathrm{I} a, 2 a$ and $3 a$ ) or no supplement (treatment 4)

\begin{tabular}{|c|c|c|c|c|c|c|c|}
\hline \multirow[b]{2}{*}{ Treatment } & \multirow[b]{2}{*}{$\mathbf{I}$} & \multirow[b]{2}{*}{ I $\mathbf{a}$} & \multirow[b]{2}{*}{$2 a$} & \multirow[b]{2}{*}{$3 a$} & \multirow[b]{2}{*}{4} & \multicolumn{2}{|c|}{$S B(42 d f)$} \\
\hline & & & & & & I, 4 & $1 \mathrm{a}, 2 \mathrm{a}, 3 \mathrm{a}$ \\
\hline Length & 776 & 789 & $78 \mathrm{I}$ & 775 & 779 & $4 \cdot 8$ & 4.5 \\
\hline $\begin{array}{l}\text { Back-fat thickn } \\
\text { Shoulder } \\
\text { Loin }\end{array}$ & $\begin{array}{l}55 \\
34\end{array}$ & $\begin{array}{l}54 \\
33\end{array}$ & $\begin{array}{l}56 \\
34\end{array}$ & $\begin{array}{l}57 \\
36\end{array}$ & $\begin{array}{l}5^{8} \\
3^{8}\end{array}$ & $\begin{array}{l}1 \cdot 3 \\
1 \cdot 3\end{array}$ & $\begin{array}{l}I \cdot 2 \\
I \cdot 3\end{array}$ \\
\hline $\begin{array}{l}\text { Eye muscle: } \\
\text { Width } \\
\text { Depth† } \\
\text { Fat: C } \\
\text { K } \\
\text { J }\end{array}$ & $\begin{array}{r}78 \\
46 \\
34 \\
58 \\
7\end{array}$ & $\begin{array}{r}82 \\
45 \\
33 \\
54 \\
8\end{array}$ & $\begin{array}{r}78 \\
44 \\
34 \\
54 \\
8\end{array}$ & $\begin{array}{r}76 \\
44 \\
34 \\
56 \\
8\end{array}$ & $\begin{array}{r}8 \mathrm{r} \\
40 \\
38 \\
56 \\
9\end{array}$ & $\begin{array}{l}1 \cdot 7 \\
I \cdot 1 \\
1 \cdot 5 \\
I \cdot 7 \\
0.5\end{array}$ & $\begin{array}{l}I .6 \\
I .0 \\
I .4 \\
I .6 \\
0.5\end{array}$ \\
\hline
\end{tabular}

- Taken according to Buck et al. (1962).

$\uparrow$ Mean values for treatments 1, I a, 2 a and 3 a did not differ significantly from one another, but each was significantly greater than the corresponding value for treatment $4(P<0.05)$. For other measurements, differences between treatments were not significant $(P>0.05)$.

Table 8. Expt 3. Mean daily live-weight gain and efficiency of food conversion over the whole experimental period, and nitrogen retained and digested in four balance periods for each pig

\begin{tabular}{|c|c|c|c|c|c|c|}
\hline Treatment & ra & $2 \mathbf{a}$ & $3 a$ & SE & $\begin{array}{l}\text { significan } \\
\text { tests" }\end{array}$ & ance \\
\hline Fish meal & $\mathrm{FM}_{24}$ & $\mathrm{FM}_{25}$ & $\mathrm{FM}_{26}$ & $(10 \mathrm{df})$ & - & \\
\hline Fish meal (\%) & 3 & 3 & 3 & - & - & \\
\hline No. of pigs & 6 & 6 & 6 & - & - & \\
\hline Initial live weight (lb) & $39 \cdot 9$ & $39 \cdot 9$ & $39 \cdot 6$ & - & - & \\
\hline Final live weight (lb) & 135.8 & $135 \cdot 6$ & $135 \% 3$ & - & - & \\
\hline $\begin{array}{l}\text { Daily live-weight } \\
\text { gain (lb) }\end{array}$ & $1 \cdot 13$ & $1 \cdot 12$ & $1 \cdot 07$ & 0.037 & $3 \mathbf{a} 2 \mathrm{a}$ & ra \\
\hline $\begin{array}{l}\text { Efficiency of food con- } \\
\text { version (lb eaten/lb } \\
\text { gained) }\end{array}$ & $2 \cdot 9 x$ & $2 \cdot 94$ & $3 \cdot 12$ & 0.057 & $\mathbf{1 a} 2 \mathbf{a}$ & $3 \mathbf{a}$ \\
\hline$N$ retained: $g /$ day & 10.9 & 10.9 & $9 \cdot 3$ & 0.27 & $3 \mathbf{a} \quad \mathbf{a}$ & $2 \mathbf{a}$ \\
\hline$\%$ & $37 \cdot 7$ & $37 \cdot 6$ & $31 \cdot 6$ & 0.82 & $3 a \quad 2 a$ & Ia \\
\hline $\begin{array}{l}\text { Apparent digestibility } \\
(\%)\end{array}$ & $73 \cdot 3$ & $70 \cdot 1$ & $66 \cdot 4$ & 0.93 & $3 a 2 a$ & $I \mathrm{a}$ \\
\hline
\end{tabular}

Expt 3. Table 8 gives the relevant results. As far as live-weight gain and efficiency of food utilization are concerned the results showed trends similar to those observed in Expt 2, but with a smaller number of pigs only the difference in efficiency of food conversion reached statistical significance $(P<0.05)$. On average, however, pigs receivingFM 24 and 25 as protein supplements gained weight faster and utilized the 
food more efficiently than pigs receiving FM 26. $\mathrm{N}$ retention, both total and as a percentage of $\mathrm{N}$ consumed, on the ration containing $\mathrm{FM}: 25$ was very similar to that on the diet with FM 24, and both rations gave significantly greater retention values than the ration containing FM $26(P<0.01)$. However, the apparent digestibility of the diet with FM 25 fell about midway between the other rations and was significantly less than that of the ration with FM 24 and significantly greater than that of the ration with FM $26(P<0.05)$.

Detailed information on the $\mathrm{N}$ metabolism of each pig within the six sets of littermates on the three different rations is given in Table 9 The values indicate that, with increasing age and weight of the pig, the amount of $\mathrm{N}$ retained and the apparent digestibility increased. The treatment differences were reasonably consistent within each litter, but there were marked between-litter differenzes.

\section{DISCUSSION}

The results of these experiments with pigs confirm the general conclusions of Bunyan \& Woodham (1964) that, as protein supplements, fish meals FM 24 and 25 are similar in quality, and both are superior to FM 26. Since FM 25 was classified by the trade as a 'fertilizer grade' fish meal, it becomes clear that such classification may be misleading.

The results of these experiments confirm the generally recognized shortcomings of total crude protein as a criterion of adequacy of the protein contained in rations for livestock. Of these three fish meals with similar crude protein content $(65.6,64.2$ and $64.5 \%$ for FM 24, 25 and 26, respectively), one has proved to be very inferior to the others in many chemical, microbiological, biological and other laboratory tests (Bunyan \& Woodham, 1964) and in the tests with pigs reported in this paper.

For some time past, efforts have been made to develcip relatively quick laboratory tests of protein quality in feeding-stuffs. The chemical 'available lysine' test of Carpenter \& Ellinger (1955) and the microbiological test of Ford (1960, 1962) appear to give a reasonable indication of overall protein quality, and their application in assessing the value of feeding-stuffs for laboratory anirnals and poultry has already proved their merits. Results of trials reported in this paper extend to pigs the range of animals for which these tests are useful indicators of the nutritive quality of protein supplements.

It is, of course, interesting that the comparative values of protein supplements for pigs are very similar to those for rats and chicks, and that several of the common biological tests for protein quality could be applied to such ingredients in the rations of pigs. Protein efficiency ratio (rat), gross protein value (chick), net protein utilization (rat), net dietary protein calories \% (rat) and now growth rate, efficiency of food conversion and $N$ retention tests on pigs have all testified the inferiority of FM 26 compared with FM 24 and 25 . The biological tests are, however, not convenient to apply in the practical feeding of livestock, mainly because of the time required to produce results, but the methods of Carpenter (1960) and of Ford (1962), which are 


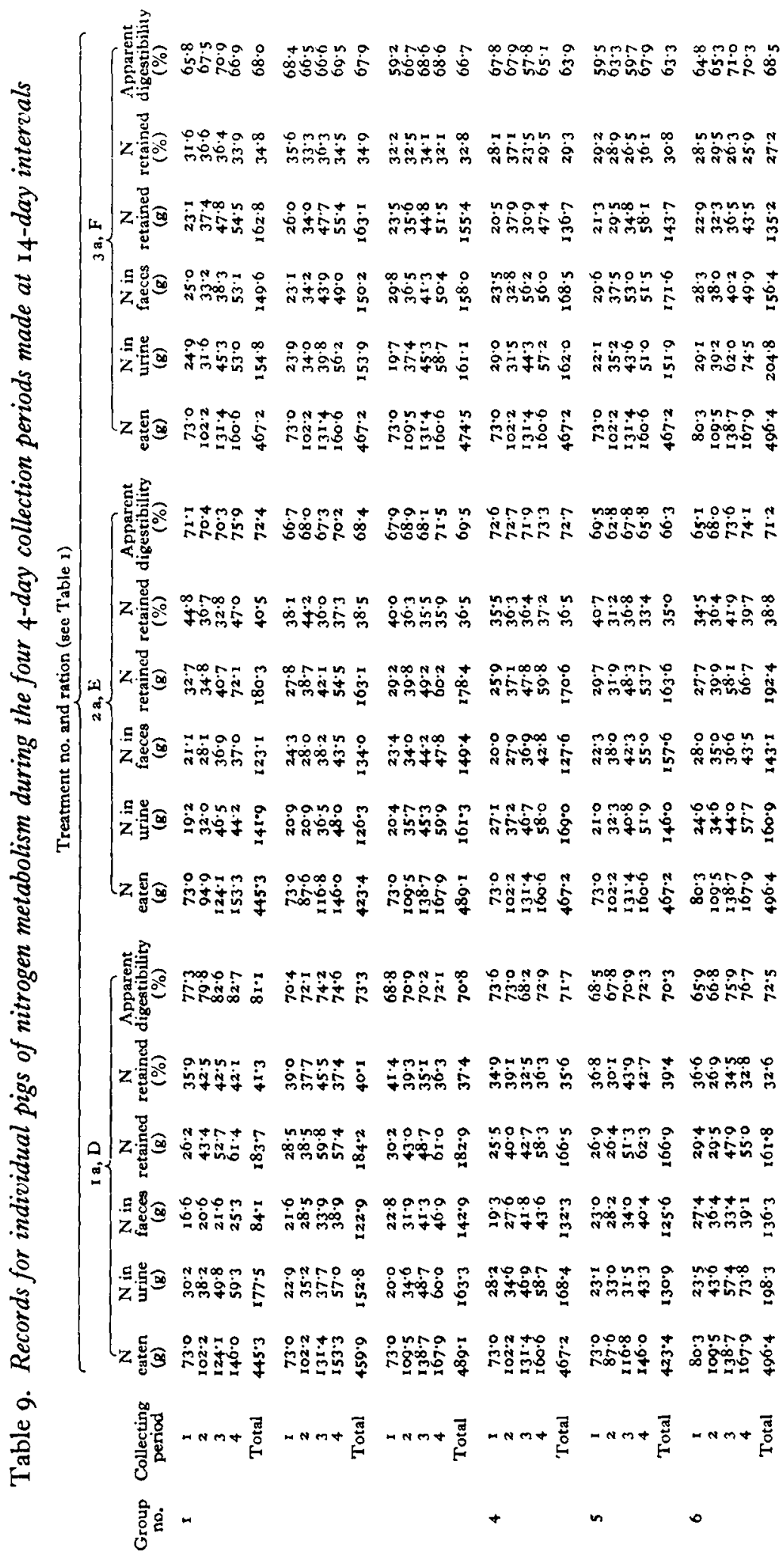


capable of evaluating the protein quality in less than $48 \mathrm{~h}$, suggest that the amount of available lysine or the relative nutritive value may eventually be used for this purpose. In this connexion the following figures from the paper by Bunyan \& Woodham (1964) are particularly relevant to the results obtained with pigs:

\begin{tabular}{|c|c|c|c|c|c|}
\hline Fish meal & $\begin{array}{l}\text { Total } \\
\text { lysine } \\
(\%)\end{array}$ & $\begin{array}{c}\text { Available } \\
\text { lysine } \\
(\%)\end{array}$ & $\begin{array}{c}\text { Total } \\
\text { methionine } \\
(\%)^{*}\end{array}$ & $\begin{array}{c}\text { Avcilable } \\
\text { methuionine } \\
(1 \%) \dagger\end{array}$ & $\begin{array}{c}\text { Relative } \\
\text { nutritive } \\
\text { valuef }\end{array}$ \\
\hline F & 6.7 & 6.6 & $2 \cdot 4,2 \cdot 6$ & $2 \cdot 4,3 \cdot 0$ & 62,65 \\
\hline & 7.5 & 6.5 & $2 \cdot 5,3 \cdot 0$ & $2 \cdot 5,3 \cdot 0$ & 76,80 \\
\hline $\mathrm{FM}_{2}$ & $6 \cdot 4$ & 4.8 & $2 \cdot 2,2 \cdot 8$ & $I \cdot 6, I \cdot 6$ & 38,50 \\
\hline
\end{tabular}

- Two replicates obtained in different laboratories (Moore \& Stein and Streptococcus zymogenes methods).

$\dagger$ Two replicates obtained in different laboratories (Strep. zymogenes and Tetrahymena pyriformis methods).

$\ddagger$ Two replicates obtained in the same laboratory.

In addition, the results provide further evidence that total lysine or total methionine content cannot be used as a guide to protein quality for pigs, the amount of available amino acids provided by the protein source being the important factor in assessing its nutritive value.

\section{SUMMARY}

I. Three fish meals, the subject of various microbiological and other laboratory tests described in the accompanying paper (Bunyan \& Woodham, 1964), were evaluated as protein supplements in the rations of growing pigs.

2. The fish meals were of similar crude protein content and were included at two levels in the pigs' rations. The criteria for assessing their quality were growth rate, efficiency of food utilization, carcass quality and nitrogen. retention and digestibility.

3. The results were similar to those obtained in the laboratory tests, two of the fish meals being equally good, and the third markedly inferior.

We thank the Directors and Staff of the Denny Group for facilities for carcass quality assessment at their Reading factory (M. Venner and Sons Ltd, Southampton Street).

\section{REFERENCES}

Allen, M. M., Barber, R. S., Braude, R. \& Mitchell, K. G. (1953). F. Anim. Tech. Ass. 14, 103. Boyne, A. W., Carpenter, K. J. \& Woodham, A. A. (196r). F. Sci. Fd Agric. 12, 832.

Braude, R. \& Mitchell, K. G. (195 I). F. Minist. Agric., Lond., 57, 501.

Buck, S. F., Harrington, G. \& Johnson, R. F. (1962). Anim. Prod. 4, 25.

Bunyan, J. \& Woodham, A. A. (1964). Brit. Y. Nutr. 18, 537.

Carpenter, K. J. (1960). Biochem. F. 77, 604.

Carpenter, K. J. \& Ellinger, G. M. (1955). Biochem. F. 61, xi.

Carpenter, K. J., Lea, C. H. \& Parr, L. J. (1963). Brit. F. Nutr. 17, I 5 I.

Duncan, D. B. (1955). Biometrics, II, I.

Ford, J. E. (1960). Brit. $尹$. Nutr. $\times 4,485$.

Ford, J. E. (1962). Brit. $\mathcal{F}$. Nutr. 16, 409 . 